\title{
The role of circulating miRNAs in multiple myeloma
}

\author{
ZHANG Ji ${ }^{1,2}$, XIAO XiaoJuan ${ }^{2} \&$ LIU Jing ${ }^{2 *}$ \\ ${ }^{1}$ Department of Hematology, The First Affiliated Hospital, University of South China, Hengyang 421001, China; \\ ${ }^{2}$ State Key Laboratory of Medical Genetics \& School of Life Sciences, Central South University, Changsha 410078, China
}

Received August 6, 2015; accepted September 6, 2015; published online November 24, 2015

\begin{abstract}
Multiple myeloma (MM) is a common malignant hematological disease. Dysregulation of microRNAs (miRNAs) in MM cells and bone marrow microenviroment has important impacts on the initiation and progression of MM and drug resistance in MM cells. Recently, it was reported that MM patient serum and plasma contained sufficiently stable miRNA signatures, and circulating miRNAs could be identified and measured accurately from body fluid. Compared to conventional diagnostic parameters, the circulating miRNA profile is appropriate for the diagnosis of MM and estimates patient progression and therapeutic outcome with higher specificity and sensitivity. In this review, we mainly focus on the potential of circulating miRNAs as diagnostic, prognostic, and predictive biomarkers for MM and summarize the general strategies and methodologies for identification and measurement of circulating miRNAs in various cancers. Furthermore, we discuss the correlation between circulating miRNAs and the cytogenetic abnormalities and biochemical parameters assessed in multiple myeloma.
\end{abstract}

miRNA, multiple myeloma, biomarker, diagnosis

Citation: Zhang J, Xiao XJ, Liu J. The role of circulating miRNAs in multiple myeloma. Sci China Life Sci, 2015, 58: 1262-1269, doi: $10.1007 / \mathrm{s} 11427-015-4969-2$

Multiple myeloma (MM) accounts for approximately $13 \%$ of all hematologic malignancies and $1 \%$ of all malignancies [1,2]. MM is a clonal B-cell malignancy characterized by the expansion of clonal plasma cells in the bone marrow, accompanied by abnormal accumulation of monoclonal antibodies [3,4]. Typically, MM evolves from a premalignant condition known as monoclonal gammopathy of undetermined significance (MGUS). The incidence of MGUS is approximately $3 \%$ in the general population 50 years of age or older, and approximately $1 \%$ of MGUS patients develop into MM each year [1]. Compared to MM, MGUS is characterized by a lower concentration of serum monoclonal antibody, less bone marrow plasmacytosis and a lack of organ damage, including hypercalcemia, renal impairment, anemia and bone lesions. Currently, there are no specific tests for distinguishing between these two conditions and estimating the risk of progression from MGUS to

*Corresponding author (email: jingliucsu @ hotmail.com)
MM. Additionally, no current strategies exist to prevent the progression from MGUS to MM; therefore, novel biomarker which may predict progression is urgently needed in MGUS patients.

miRNAs are an abundant class of regulatory noncoding single-stranded RNA molecules approximately 20-23 nucleotides long. In general, miRNAs bind with imperfect complementarity to the 3 '-untranslated region $\left(3^{\prime}\right.$-UTR (untranslated regions)) of a specific target mRNA to promote its degradation and/or inhibit its translation [5]. Many miRNAs display regulatory roles in all major biological processes, including cell motility, differentiation, proliferation and apoptosis [6,7]. Aberrant miRNA expression profiles are frequently discovered during the initiation and progression of cancers, including early or advanced disease stages, response, remission and relapse. Recently, it has been demonstrated that miRNAs are secreted into body fluids, including serum and plasma, and can maintain stability while freely circulating in the bloodstream. 


\section{1 miRNAs and MM}

As growing research has indicated that miRNAs played important roles in the occurrence, development, recurrence and drug resistance of MM, miRNA signatures may serve as potential biomarkers for myeloma diagnosis, prognosis, and response to treatment. For example, hemizygous and/or homozygous chromosomal deletion at the 13q14 locus in MM patients can result in the loss of or reduction in expression of miR-15 and miR-16, which is correlated with tumorigenesis and the development of MM [8,9]. Pichiorri et al. [10] first described comprehensive global miRNA expression profiling of MM, MGUS and normal plasma cells, which indicated that MM miRNA signatures modulated the expression of proteins critical to myeloma pathogenesis. In 2010, Gutierrez et al. [11] investigated the association between miRNA expression profiles and their corresponding target genes and found that the downregulation of several miRNAs resulted in overexpression of cyclin D2 (CCND2) in MM. These authors demonstrated for the first time that miRNA expression patterns in MM were associated with genetic abnormalities. Yyusnita et al. [12] revealed that several miRNAs, including downregulated let-7c and miR-16 and upregulated miR-449, miR-181a and miR-181b, exhibited similar expression patterns in peripheral blood compared to data obtained from bone marrow aspirates of MM patients. However, certain miRNAs, including miR-21, the miR-106b-25 cluster and miR-181a/b, promoted oncogenic activity during the malignant transformation of plasma cells in MM and MGUS [10]. Furthermore, patients with high expression levels of the miR-17-92 cluster had shorter progression-free survival (PFS) compared to those with low level expression, suggesting that this cluster of miRNAs was associated with tumorigenesis and poor prognosis in MM [13]. Additionally, miR-21 may display an oncogenic role in MM; therefore, antagonism of miR-21 by oligonucleotide inhibitors may result in antitumor activity against MM [14]. More recently, circulating miRNAs in body fluids (serum and plasma) have been shown to be significantly associated with MM pathogenesis.

Recently, a variety of evidences suggested interaction between MM cells and bone marrow microenvironment (BMME) components played an increasingly important role in $\mathrm{MM}$ pathogenesis and progression. Aberrant expression of some miRNAs in MM-BMSCs (bone marrow stromal cells) or exosome resulted in altered expression of miR-related targets including cytokines, adhesion molecules, DNA methyltransferase and signaling molecules (Table 1) [15-21]. It has been confirmed that interleukin-17 (IL-17) produced by the tumor microenvironment played a crucial role in promoting cell proliferation, inhibiting cellular and facilitating cell migration. Sun et al. demonstrated that negative correlation between miR-192 expression and IL-17 or IL-17RA expression was observed in bone marrow specimens derived from MM patients [15]. Furthermore, Shen et al. [16] indicated that miR-202 served as a negative modulator that can regulate BAFF by inhibiting MM cell survival, growth, and adhesion in BMME. Up-expression of miR-202 in BMSCs resulted in MM cells more sensitive to bortezomib. More interestingly, a recent study suggested that exosomal miR-135b endosome-derived from hypoxia-resistant MM (HR-MM) cells can control MM angiogenesis through directly inhibiting the expression of factor-inhibiting hypoxia-inducible factor 1 (FIH-1) in endothelial cells [17].

\section{Biogenesis and strategies for the identifica- tion of circulating miRNA in cancer}

It remains unclear whether cell-free tumor-related miRNAs

Table 1 Overview of specific miRNAs and their role in the MM microenviroment

\begin{tabular}{|c|c|c|c|c|}
\hline miRNA & $\begin{array}{l}\text { Up-regulation/ } \\
\text { Down-regulation }\end{array}$ & Gene targets & Description of miRNAs functions & Reference \\
\hline miR-192 miR-215 & Down-regulation & IL-17Rs(IL-17RA and IL-17RE) & $\begin{array}{l}\text { IL-17/miR-192/IL-17Rs regulatory feedback loop } \\
\text { regulated MM cell proliferation, apoptosis and migra- } \\
\text { tion }\end{array}$ & {$[15]$} \\
\hline miR-202 & Down-regulation & B cell-activating factor (BAFF) & $\begin{array}{l}\text { Regulating MM cell survival, growth, and adhesion in } \\
\text { BMME and induction of BMSC mediated drug re- } \\
\text { sistance }\end{array}$ & [16] \\
\hline $\operatorname{miR}-135 b$ & Up-regulation & $\begin{array}{l}\text { Facter-inhibiting hypoxia-inducible } \\
\text { factor } 1 \text { (FIH-1) }\end{array}$ & $\begin{array}{l}\text { Exosomal miR-135b suppressed FIH-1 in endothelial } \\
\text { cells and regulated tumor angiogenesis }\end{array}$ & [17] \\
\hline $\begin{array}{l}\operatorname{miR}-126-3 p \\
\operatorname{miR}-140\end{array}$ & Down-regulation & $\begin{array}{l}\text { DNA methyltransferase-1 } \\
\text { (DNMT-1) }\end{array}$ & $\begin{array}{l}\text { miR-126-3p and miR-140 suppressed DNMT1 expres- } \\
\text { sion and re-expressed RANKL in MM cells }\end{array}$ & {$[18]$} \\
\hline miR-29b & Down-regulation & DNMT-3A and DNMT-3B & $\begin{array}{l}\text { miR-29b inhibited DNMT-3A and DNMT-3B expres- } \\
\text { sion and reduced global DNA methylation }\end{array}$ & [19] \\
\hline $\operatorname{miR}-21$ & Up-regulation & RhoB & $\begin{array}{l}\text { Induction of BMSC-mediated drug resistance in MM } \\
\text { cells partially through NFKB pathway and by repress- } \\
\text { ing RhoB }\end{array}$ & {$[20]$} \\
\hline $\mathrm{miR}-15 \mathrm{a} / 16$ & Down-regulation & Not mentioned & $\begin{array}{l}\text { IL- } 6 \text { secreted by BMSCs inhibited miR- } 15 \mathrm{a} / 16 \text { ex- } \\
\text { pression and promoted drug-resistance in myeloma } \\
\text { cells }\end{array}$ & [21] \\
\hline
\end{tabular}


in the circulation are secreted by tumor cells or immunocytes in the tumor microenvironment or are the by-product of tumor cell death and lysis. One hypothesis is that passive release occurs during cell injury [22]. A second opinion is that the high rate of proliferation and cell lysis in tumors might contribute to the abundance of miRNAs in the circulation because a pattern of nonspecific miRNA release has been observed in various tumors [23]. Furthermore, the third possibility is that massive circulating miRNAs derive from immunocytes in the tumor microenvironment or the immune response regulated by the appropriate organ system [24]. Cell-free miRNAs in the blood stream are very stable and can be protected from degradation by encapsulation in lipid vesicles including microvesicles, exosomes, and apoptotic bodies. These vesicles are capable of binding with argonaute 2 (AGO2), nucleophosmin 1 (NPM1) and high- density lipoprotein (HDL). Additionally, understanding the origins of circulating miRNAs requires insight into the association between expression levels of circulating miRNAs and the corresponding tumor cells that they affect. Most studies found consistent trends between changes in tumor tissue miRNAs and those observed in circulating miRNAs $[25,26]$. However, some of the cellular miRNAs may be selectively released into the serum [27]. Therefore, it is feasible to distinguish pathogenesis from normal physiology by the detection of certain circulating miRNAs originating from different tissue cells.

In general, strategies for identifying tumor-related circulating miRNAs employ similar methodologies among various cancers (Figure 1). The first step is efficient extraction and purification of miRNAs from serum or plasma. It is important to avoid miRNA degradation and contamination

Extraction and purification of circulating microRNAs

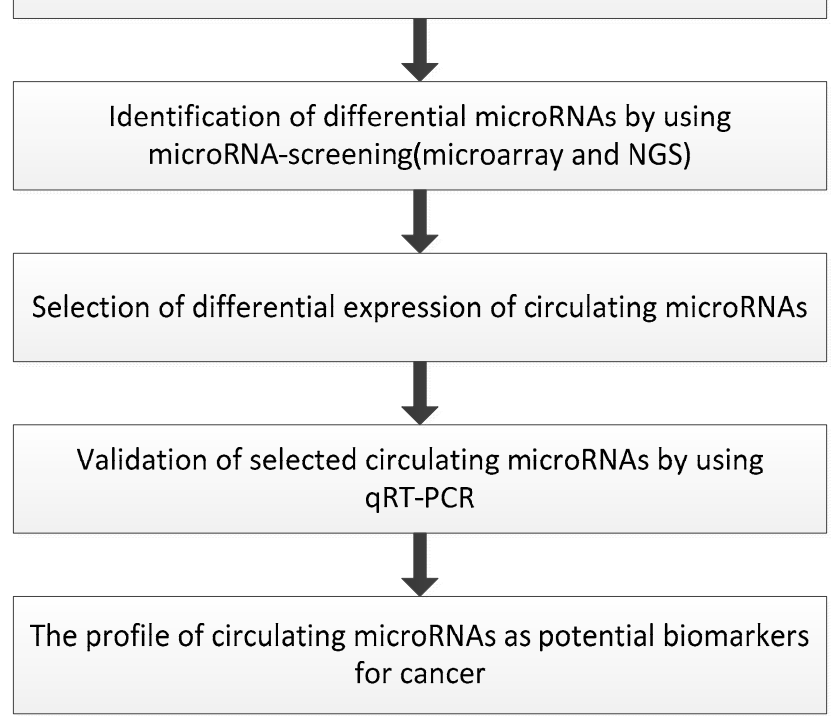

Figure 1 Flow chart of experimental design for the identification of circulating miRNA biomarkers in cancer. by additional substances in body fluids. Contaminations may result from the presence of intact blood cells in the serum or plasma or lysis of these cells (hemolysis) during sampling and processing [28-30].

After purification, it is vital to obtain global profiles of miRNA signatures and compare the differential expression of miRNAs between tumor patients and healthy controls using the following three methodologies: qRT-PCR, miRNA microarray, and next-generation sequencing (NGS). Diagnostics based on circulating miRNAs rely on accurate measurements of miRNAs from the serum or plasma with high sensitivity and precision. Real time RT-PCR has been widely used as a sensitive and precise tool to detect low-abundance circulating miRNAs; however, there are crucial methodological challenges involved in the normalization during detection of circulating miRNAs. Recent studies have indicated that a combination of several miRNAs can serve as a stable reference for the normalization of circulating miRNAs, and this method is statistically superior to the single reference gene approach previously used [31,32]. Moreover, to accurately determine the differential expression of miRNAs between groups, absolute quantification of circulating miRNAs appears to be the more reliable way. NGS and microarray are also effective techniques for identification of circulating miRNAs, but are less frequently used due to increased starting material requirements. Furthermore, the validation of NGS and microarray data need subsequently perform at the individual patient level by qRT-PCR. In particular, the application of NGS and microarray techniques is challenging for most laboratories as these approaches are expensive to validate and NGS itself remains costly and labor intensive. These issues may explain why qRTPCR-based profiling strategies are more frequently used [33]. However, NGS has the notable advantage of distinguishing among unknown RNA species that would not be amplified by qRT-PCR. This may correlate with the emerging notion that miRNA $5^{\prime}$ - and $3^{\prime}$-end structural variants, termed isomiRs, are frequently expressed and have been linked to tumorigenesis [34].

\section{Diagnostic, prognostic and predictive bi- omarkers of circulating miRNA in MM}

Distinctive circulating miRNAs profiles may be observed in MM patients compared to healthy donors and MGUS patients, and this provides an important auxiliary tool for distinguishing MM patients from healthy controls and MGUS patients (Table 2). Kubiczkova et al. [35] obtained serum miRNA expression profiles by taqman low density arrays (TLDA), and validated these results by qRT-PCR in a cohort of newly diagnosed, relapsed MM and MGUS patients. A combination of miR-34a and let-7e could distinguish MM patients from healthy individuals with a sensitivity of $80.6 \%$ and a specificity of $86.7 \%$; MGUS patients could be distin- 
Table 2 Synopsis of the potential of circulating miRNAs as biomarkers of MM

\begin{tabular}{|c|c|c|c|c|c|}
\hline Body fluid & Sample size & Methodology & Upregulated-miR & $\begin{array}{l}\text { Downregulated- } \\
\text { miR }\end{array}$ & References \\
\hline Serum & $\begin{array}{l}\text { Newly diagnosed MM patients }(n=103) \\
\text { vs MM patients in relapse }(n=18) \text { vs } \\
\text { MGUS }(n=57) \text { vs healthy donors }(n=30)\end{array}$ & $\begin{array}{l}\text { Taqman low density miRNA ar- } \\
\text { rays (TLDA) and qRT-PCR }\end{array}$ & $\operatorname{miR}-34 a$ & $\begin{array}{l}\text { let-7d } \\
\text { let-7e } \\
\text { miR-130a } \\
\text { miR-744 }\end{array}$ & {$[35]$} \\
\hline Serum & $\begin{array}{l}\text { MGUS patients }(n=15) \text { vs MM patients } \\
(n=24) \text { vs normal hospitalized controls } \\
(n=20) \text { vs normal healthy controls }(n=13)\end{array}$ & Microarray and qRT-PCR & $\begin{array}{l}\operatorname{miR}-1246 \\
\operatorname{miR}-720\end{array}$ & miR-1308 & {$[36]$} \\
\hline Plasma & $\begin{array}{l}\text { Symptomatic MM ( } n=138) \text { vs smolder- } \\
\text { ing MM }(n=8) \text { vs MGUS }(n=22) \text { vs } \\
\text { healthy volunteers }(n=21)\end{array}$ & $\begin{array}{l}\text { Taqman low density miRNA ar- } \\
\text { rays (TLDA) and qRT-PCR }\end{array}$ & $\begin{array}{l}\text { miR-146a } \\
\text { miR-16 } \\
\text { miR-186 } \\
\text { miR-454 } \\
\text { miR-483-5p }\end{array}$ & $\begin{array}{l}\text { miR-17 } \\
\text { miR-19a } \\
\text { miR-19b } \\
\text { miR-20a } \\
\text { miR-92a }\end{array}$ & {$[37]$} \\
\hline Serum & $\begin{array}{l}\text { MM patients }(n=91) \text { vs healthy controls } \\
(n=30)\end{array}$ & qRT-PCR & $\begin{array}{l}\text { miR-142-5p } \\
\text { miR-29a } \\
\text { miR-660 }\end{array}$ & - & {$[38]$} \\
\hline Serum & $\begin{array}{l}\text { MM patients }(n=40) \text { vs healthy controls } \\
(n=30)\end{array}$ & qRT-PCR & miR-202 & - & [39] \\
\hline Plasma & $\begin{array}{l}\text { Newly diagnosed MM patients }(n=40) \text { vs } \\
\text { healthy individuals }(n=20)\end{array}$ & Microarray and qRT-PCR & $\operatorname{miR}-483-5 p$ & $\operatorname{miR}-20 \mathrm{a}$ & {$[40]$} \\
\hline Serum & $\begin{array}{l}\text { Newly diagnosed symptomatic } \text { MM } \\
\text { patients }(n=108) \text { vs healthy donors } \\
(n=56)\end{array}$ & Microarray and qRT-PC & $\begin{array}{l}\text { miR-135b-5p } \\
\text { miR-214-3p } \\
\text { miR-33b } \\
\text { miR-3658 } \\
\text { miR-4254 }\end{array}$ & $\begin{array}{l}\operatorname{miR}-19 a \\
\operatorname{miR}-92 a\end{array}$ & {$[41]$} \\
\hline Plasma & $\begin{array}{l}\text { MM patients }(n=40) \text { vs healthy controls } \\
(n=28)\end{array}$ & $\begin{array}{l}\text { Taqman low density miRNA ar- } \\
\text { rays (TLDA) and qRT-PCR }\end{array}$ & $\begin{array}{l}\text { miR-148 } \\
\text { miR-181a } \\
\text { miR-20a } \\
\text { miR-221 } \\
\text { miR-99b }\end{array}$ & - & {$[42]$} \\
\hline Serum & $\begin{array}{l}\text { MM patients }(n=38) \text { vs MGUS }(n=8) \text { vs } \\
\text { healthy controls vs paired MM patients } \\
(n=17) \text { at CR and relapse after autolo- } \\
\text { gous stem-cell transplantation (ASCT) }\end{array}$ & $\begin{array}{l}\text { TaqMan human microRNA } \\
\text { arrays and qRT-PCR }\end{array}$ & - & $\begin{array}{l}\text { miR-16 } \\
\text { miR-25 } \\
\text { miR-20a } \\
\text { miR-25 } \\
\text { miR-660 }\end{array}$ & {$[43]$} \\
\hline
\end{tabular}

guished from healthy donors with a sensitivity of $91.1 \%$ and a specificity of $96.7 \%$. Jones et al. [36] revealed that circulating miR-720 and miR-1246 were upregulated, and miR-1308 downregulated in MM patient sera. Further study found that the combination of miR-720 and miR-1308 was useful in distinguishing healthy controls, as well as patients with unrelated diseases from pre-cancerous myeloma and MM patients. Additionally, miR-1246 and miR-1308 expression could distinguish MGUS from MM patients [36]. Furthermore, low expression of plasma miR-92a in symptomatic MM patients was found compared with healthy donors [37]. As previously reported, miR-92a was identified as the most important potential diagnostic marker in several malignancies, including colorectal cancer [44], breast cancer [27], non-Hodgkin's lymphoma [45], and gastric cancer [46]. The upregulation of miR-29a was helpful in discrimination between $\mathrm{MM}$ and healthy donors with a sensitivity of $88 \%$ and a specificity of $70 \%$ [38]. The miR-202 expression was significantly higher in MM patients than in healthy controls, and the sensitivity and specificity for miR-202 in this diagnosis of MM patients were $80.0 \%$ and $60.0 \%$, respectively [39]. Recently, increased miR-483-5p and decreased miR-20a expression display a diagnostic role in discriminating between $\mathrm{MM}$ patients and healthy subjects [40]. Furthermore, Hao et al. [41] found that a combination of miR-19a and miR-4254 could distinguish MM patients from healthy controls with a sensitivity of $91.7 \%$ and a specificity of $90.5 \%$.

More recently, some studies have supported the fact that circulating miRNAs could function as non-invasive biomarkers to estimate the prognosis of $\mathrm{MM}$ patients. miR-744 and let-7e were verified as possible indicators of survival in MM, and low miR-744 and let-7e levels were associated with shorter overall survival (OS) and remission, and shorter time to progression compared to patients with high expression of these molecules [35]. These poor clinical outcomes can be partially explained by the fact that the gene for miR-744 is located in the $17 \mathrm{q} 12$ region where various tumor-related genes are closely situated, including TP53, BRCA1, and FBXO47. Deletion of chromosome 17q12 has been previously associated with poor survival in cancers $[47,48]$. Furthermore, the high levels of circulating miR-20a was positively correlated with miR-148a and shorter relapse-free time (RFT) in MM patients [42]. Additionally, expression of some miRNAs showed dynamic changes in MM plasma or serum during disease progression, and thus, continual detection of miRNA levels was beneficial for monitoring disease status and assessing the 
prognoses of MM patients. Yoshizawa et al. [37] found that differential expression of miR-92a in different stages of MM. miR-92a plasma levels were lower in partial MM patients and did not normalize normal in subjects with a partial response (PR) or very good PR to treatment, however, miR-92a levels did reach baseline in subjects who achieved complete remission. A recent study indicated that high miR-92a serum levels showed an independent correlation with poor survival in colorectal cancer [49]. The detection of miR-34a and let-7d was helpful in assessing the prognosis of MM, and high miR-34a expression and low let-7d expression were observed in relapsed MM patients compared to levels in patients at the time of diagnosis [38]. Qu et al. [40] revealed that miR-483-5p showed association with PFS, and the median PFS was 15 mon in patients with high miR-483-5p levels compared to 21 mon in patients with low miR-483-5p levels.

MGUS is usually referred as an asymptomatic precancerous stage of malignant expansion of a clonal plasma cell. A good biomarker is urgently required and would be of great value for predicting MM tumorigenesis in MGUS patients and discriminating between these two conditions. Recently, Jones et al. [36] revealed that the combination of miRNA-1246 and -1308 expression can distinguish MM from MGUS with a sensitivity of $79.2 \%$ and a specificity of $66.7 \%$. Unfortunately, no single serum miRNA was able to discriminate between these two conditions. Moreover, plasma miR-92a concentration may serve as a biomarker for monitoring the therapeutic response and assessing disease progression from MGUS to MM. The miR-92a plasma level in MUGS patients was significantly higher compared to that in MM patients, but there was no significant difference in plasma miR-92a levels between MM patients with smoldering disease and MGUS patients. Furthermore, the expression of plasma miR-92a in MGUS patients maybe act as a promising parameter not only for determining disease status but also whether further treatment was required [37]. Reportedly, combination with miR-19b and miR-331 was a marker of shorter PFS, because longer PFS after ASCT was associated with high expression of miR-19b or miR-331 in MM patients [43].

\section{Circulating miRNA expression patterns are associated with biochemical parameters in MM}

Spearman bivariate correlation was performed to understand the relevance of circulating miRNA expression levels to clinical parameters in MM patients (Table 3). The results indicated that expression levels of four miRNAs (miR-744, miR-130a, let-7d and let-7e) showed positive correlations with hemoglobin and thrombocyte counts; however, expression of these miRNAs was also negatively correlated with levels of creatinine and $\beta 2$-microglobulin. Furthermore, miRNA-34a was negatively correlated with hemoglobin. Three circulating miRNAs including miR-744, let-7d and let-7e were positively correlated with albumin levels, whereas miRNA-34a showed a significant negative correlation with albumin. In particular, let-7e levels showed significant negative correlations with the level of monoclonal immunoglobulin [35]. Jones et al. [36] demonstrated that miR-1246 showed a slight significant inverse correlation with paraprotein (M-protein), which indicated that miRNA-1246 expression may be suppressed by increased paraprotein production or secretion. $\mathrm{Yu}$ et al. [39] found that the relative expression of serum miR-202 was higher in MM patients compared to healthy subjects, and significantly positively correlated with serum $\beta 2$-microglobulin and $\kappa$ light chain concentrations but was not correlated with the lactic acid dehydrogenase (LDH) and $\lambda$ light chain concentrations.

\section{Circulating miRNA expression is associated with cytogenetic abnormalities in MM}

Detailed genomic analysis has revealed that MM was characterized by complex cytogenetic abnormalities, such as chromosomal translocations involving mutations of $\mathrm{t}(4 ; 14)$, $\mathrm{t}(6 ; 14)$ and $\mathrm{t}(14 ; 16)$; deletion of $13 \mathrm{q} 14$ and $17 \mathrm{p} 13$; rearrangement of immunoglobulin heavy-chain genes (IGH); and amplification of 1q21 [50-53]. The tumor suppressor p53 which is located in $17 \mathrm{p} 13.1$ is rarely inactivated by

Table 3 Correlation between circulating miRNAs and biochemical parameters in MM

\begin{tabular}{|c|c|c|c|}
\hline miRNA & Biochemical parameters & Negative/Positive & References \\
\hline \multirow[t]{3}{*}{ miR-130a, miR-744, let-7d, let-7e } & Hemoglobin & Positive & {$[35]$} \\
\hline & Thrombocytes count & Positive & \\
\hline & Creatinine and $\beta 2$-microglobulin & Negative & \\
\hline let-7d, let-7e, $\operatorname{miR}-744$ & Albumin & Positive & \\
\hline let-7e, miR-744 & C-reactive protein $(\mathrm{CRP})$ & Negative & \\
\hline let-7e & Monoclonal immunoglobulin (Ig) & Negative & \\
\hline \multirow[t]{2}{*}{$\operatorname{miR}-34 a$} & Hemoglobin & Negative & \\
\hline & Albumin & Negative & \\
\hline miR-1246 & Paraprotein (M-protein) & Negative & [36] \\
\hline $\operatorname{miR}-202$ & $\beta 2$-microglobulin and $\kappa$ light chain concentrations & Positive & {$[39]$} \\
\hline
\end{tabular}


Table 4 Correlation between circulating miRNAs and cytogenetic abnormalities in MM

\begin{tabular}{lll}
\hline miRNA & Cytogenetic abnormalities & Negative/Positive \\
\hline let-7e, miR-744 & $\operatorname{del}(13 q)$ & Negative \\
miR-19a & $\operatorname{del}(13 q 14)$ and 1q21 amplification & Positive \\
miR-99b & $\mathrm{t}(4 ; 14)$ & Positive \\
miR-211 & $\operatorname{del}(13 q)$ & Negative \\
\hline
\end{tabular}

mutations or deletions, the ectopic expression of p53 can downregulate miR-192, miR-194, and miR-215 in a subset of newly diagnosed MM patients. These miRNAs serve as enhancers in the pharmacological activation of the p53 pathway, in addition, they target the insulin-like growth factor (IGF) pathway, preventing enhanced migration of plasma cells into bone marrow [54]. Huang et al. [42] investigated the cytogenetic aberrations of $12 \mathrm{MM}$ patients using micro-FISH, and detected serum miRNA expression by qRT-PCR. Interestingly, a high level of miR-99b expression was associated with a $\mathrm{t}(4 ; 14)$ translocation (IGH; FGFR3) (Table 4), which suggested that miRNA-99b maybe promote oncogenesis in MM. Furthermore, the presence of a $\mathrm{t}(4 ; 14)$ chromosomal abnormality consistently indicated poor prognosis in MM patients [55]. Deletion of chromosome 13 was a common cytogenetic abnormality in MM and was associated with the clonal expansion of MM cells $[8,9,56]$. miR-221, an important oncogenic miRNA, was upregulated in numerous MM patients [57,58]. Expression of plasma miR-221 was specifically upregulated in the sera of MM patients compared to healthy controls, however, the miR-221 expression level was lower in MM samples with $\operatorname{del}(13 q)$ than in those without $\operatorname{del}(q 13)$ [42]. In addition, the presence of $\operatorname{del}(13 \mathrm{q} 14)$ in MM patients has a significant correlation with lower levels of let-7e, as well as miR-744, in the serum, which indicated worse OS and time to progression (TTP) [35]. Several studies have reported that lower levels of miR-744 were associated with 1q12 amplification or $\mathrm{t}(4 ; 14)$ in MM cells, both of which have been previously described as poor prognostic indicators for MM [59,60].

\section{Circulating miRNA expression is associated with drug resistance in $\mathrm{MM}$}

miRNA expression profiles are useful for prognosticating clinical resistance in MM patients. Aberrant expression of numerous miRNAs has also been observed in the drug-resistant myeloma cell lines, suggesting that dysregulated miRNA might be involved in the generation of drug resistant MM cells [61,62]. Hao et al. [21] identified that miRNA-15a/-16 expressions significantly correlated with drug resistance of MM cells. Expression of miRNA-15a/-16 was suppressed by interleukin-6 (IL-6) produced by BMSCs, which resulted in significantly increasing growth and survival of MM cells after treatment with cytotoxic agents. Serum miR-19a can function as a valuable predictor of PFS and OS in MM patients. MM patients with low miR-19a levels had improved responses to bortezomib compared to subjects with high miR-19a expression, experienced a significantly extended survival upon bortezomib-based therapy [41]. Qu et al. [40] indicated that the median PFS of patients with high levels of plasma miR-483-5p was 15 mon, in comparison with 21 mon for patients with low levels of plasma miR-483-5p after application of several chemotherapy regimens including TAD, VD, TCD, PAD, TD and VTD.

\section{Conclusions}

Exploration of circulating miRNAs as novel biomarkers for MM is still a "booming" field. Growing studies indicate that the expression profiles of circulating miRNAs are valuable tools to diagnose patients and estimate prognosis as well as predicting response to treatment, clinical therapeutic outcomes, and disease recurrence. However, some critical problems must be resolved to establish circulating miRNAs as biomarkers for MM. First, it is helpful to understand whether circulating miRNAs originate from tumor cell death and lysis, or instead from secretion by tumor cells or immunocytes in blood circulation. Furthermore, identifying the relationship between tissue miRNAs and circulating miRNAs will be valuable to elucidate the origin and function of circulating miRNAs. Second, to improve the diagnostic accuracy of this approach, a well-characterized panel of miRNAs specific to MM, MGUS, and chemotherapeutic responses should be established. Finally, larger sample sets including long-term clinical data are urgently required for future studies because these recent results are from small studies that lack long-term outcome data. In the coming years, we believe that widespread application of miRNA biomarkers in clinical practice will become routine in the diagnosis, prognosis and prediction of MM.

The author(s) declare that they have no conflict of interest.

This work was supported by the National Natural Science Foundation of China (81301774, 81470362).

1 Kyle RA, Rajkumar SV. Multiple myeloma. Blood, 2008, 111: 2962-2972

2 Terpos E, Politou M, Rahemtulla A. The role of markers of bone 
remodeling in multiple myeloma. Blood Rev, 2005, 19: 125-142

3 Mahindra A, Hideshima T, Anderson KC. Multiple myeloma: biology of the disease. Blood Rev, 2010, 24 Suppl 1: S5-S11

4 Hajek R, Okubote SA, Svachova H. Myeloma stem cell concepts, heterogeneity and plasticity of multiple myeloma. Br J Haematol, 2013, 163: 551-564

5 Liu B, Sun L, Song E. Non-coding RNAs regulate tumor cell plasticity. Sci China Life Sci, 2013, 56: 886-890

6 Xie S, Zhang Y, Qu L, Xu H. A Helm model for microRNA regulation in cell fate decision and conversion. Sci China Life Sci, 2013, 56: 897-906

7 Peng L, Li Y, Zhang L, Yu W. Moving RNA moves RNA forward. Sci China Life Sci, 2013, 56: 914-920

8 Roccaro AM, Sacco A, Thompson B, Leleu X, Azab AK, Azab F, Runnels J, Jia X, Ngo HT, Melhem MR, Lin CP, Ribatti D, Rollins BJ, Witzig TE, Anderson KC, Ghobrial IM. MicroRNAs 15a and 16 regulate tumor proliferation in multiple myeloma. Blood, 2009, 113: 6669-6680

9 Corthals SL, Jongen-Lavrencic M, de Knegt Y, Peeters JK, Beverloo HB, Lokhorst HM, Sonneveld P. Micro-RNA-15a and micro-RNA-16 expression and chromosome 13 deletions in multiple myeloma. Leuk Res, 2010, 34: 677-681

10 Pichiorri F, Suh SS, Ladetto M, Kuehl M, Palumbo T, Drandi D, Taccioli C, Zanesi N, Alder H, Hagan JP, Munker R, Volinia S, Boccadoro M, Garzon R, Palumbo A, Aqeilan RI, Croce CM. MicroRNAs regulate critical genes associated with multiple myeloma pathogenesis. Proc Natl Acad Sci USA, 2008, 105: 12885-12890

11 Gutierrez NC, Sarasquete ME, Misiewicz-Krzeminska I, Delgado M, De Las Rivas J, Ticona FV, Ferminan E, Martin-Jimenez P, Chillon C, Risueno A, Hernandez JM, Garcia-Sanz R, Gonzalez M, San Miguel JF. Deregulation of microRNA expression in the different genetic subtypes of multiple myeloma and correlation with gene expression profiling. Leukemia, 2010, 24: 629-637

12 Yyusnita, Norsiah, Zakiah I, Chang KM, Purushotaman VS, Zubaidah Z, Jamal R. MicroRNA (miRNA) expression profiling of peripheral blood samples in multiple myeloma patients using microarray. Malays J Pathol, 2012, 34: 133-143

13 Chen L, Li C, Zhang R, Gao X, Qu X, Zhao M, Qiao C, Xu J, Li J. miR-17-92 cluster microRNAs confers tumorigenicity in multiple myeloma. Cancer Lett, 2011, 309: 62-70

14 Leone E, Morelli E, Di Martino MT, Amodio N, Foresta U, Gulla A, Rossi M, Neri A, Giordano A, Munshi NC, Anderson KC, Tagliaferri $\mathrm{P}$, Tassone $\mathrm{P}$. Targeting miR-21 inhibits in vitro and in vivo multiple myeloma cell growth. Clin Cancer Res, 2013, 19: 2096-2106

15 Sun Y, Pan J, Mao S, Jin J. IL-17/miR-192/IL-17Rs regulatory feedback loop facilitates multiple myeloma progression. PLoS One, 2014, 9: e114647

16 Shen X, Guo Y, Yu J, Qi J, Shi W, Wu X, Ni H, Ju S. miRNA-202 in bone marrow stromal cells affects the growth and adhesion of multiple myeloma cells by regulating B cell-activating factor. Clin Exp Med, 2015, in press

17 Umezu T, Tadokoro H, Azuma K, Yoshizawa S, Ohyashiki K, Ohyashiki JH. Exosomal miR-135b shed from hypoxic multiple myeloma cells enhances angiogenesis by targeting factor-inhibiting HIF-1. Blood, 2014, 124: 3748-3757

18 Yuan L, Chan GC, Fung KL, Chim CS. RANKL expression in myeloma cells is regulated by a network involving RANKL promoter methylation, DNMT1, microRNA and TNFalpha in the microenvironment. Biochim Biophys Acta, 2014, 1843: 1834-1838

19 Amodio N, Leotta M, Bellizzi D, Di Martino MT, D’Aquila P, Lionetti M, Fabiani F, Leone E, Gulla AM, Passarino G, Caraglia M, Negrini M, Neri A, Giordano A, Tagliaferri P, Tassone P. DNA-demethylating and anti-tumor activity of synthetic miR-29b mimics in multiple myeloma. Oncotarget, 2012, 3: 1246-1258

20 Wang X, Li C, Ju S, Wang Y, Wang H, Zhong R. Myeloma cell adhesion to bone marrow stromal cells confers drug resistance by microRNA-21 up-regulation. Leuk Lymphoma, 2011, 52: 1991-1998

21 Hao M, Zhang L, An G, Sui W, Yu Z, Zou D, Xu Y, Chang H, Qiu L. Suppressing miRNA-15a/-16 expression by interleukin- 6 enhances drug-resistance in myeloma cells. J Hematol Oncol, 2011, 4: 37

22 Ji X, Takahashi R, Hiura Y, Hirokawa G, Fukushima Y, Iwai N. Plasma miR-208 as a biomarker of myocardial injury. Clin Chem, 2009, 55: 1944-1949

23 Valadi H, Ekstrom K, Bossios A, Sjostrand M, Lee JJ, Lotvall JO. Exosome-mediated transfer of mRNAs and microRNAs is a novel mechanism of genetic exchange between cells. Nat Cell Biol, 2007, 9: 654-659

24 Hunter MP, Ismail N, Zhang X, Aguda BD, Lee EJ, Yu L, Xiao T, Schafer J, Lee ML, Schmittgen TD, Nana-Sinkam SP, Jarjoura D, Marsh CB. Detection of microRNA expression in human peripheral blood microvesicles. PLoS One, 2008, 3: e3694

25 Lee JC, Zhao JT, Clifton-Bligh RJ, Gill A, Gundara JS, Ip JC, Glover A, Sywak MS, Delbridge LW, Robinson BG, Sidhu SB. MicroRNA-222 and microRNA-146b are tissue and circulating biomarkers of recurrent papillary thyroid cancer. Cancer, 2013, 119: 4358-4365

26 Hongliang C, Shaojun H, Aihua L, Hua J. Correlation between expression of miR-155 in colon cancer and serum carcinoembryonic antigen level and its contribution to recurrence and metastasis forecast. Saudi Med J, 2014, 35: 547-553

27 Chan M, Liaw CS, Ji SM, Tan HH, Wong CY, Thike AA, Tan PH, Ho GH, Lee AS. Identification of circulating microRNA signatures for breast cancer detection. Clin Cancer Res, 2013, 19: 4477-4487

28 Duttagupta R, Jiang R, Gollub J, Getts RC, Jones KW. Impact of cellular miRNAs on circulating miRNA biomarker signatures. PLoS One, 2011, 6: e20769

29 McDonald JS, Milosevic D, Reddi HV, Grebe SK, Algeciras-Schimnich A. Analysis of circulating microRNA: preanalytical and analytical challenges. Clin Chem, 2011, 57: 833-840

30 Kirschner MB, Kao SC, Edelman JJ, Armstrong NJ, Vallely MP, van Zandwijk N, Reid G. Haemolysis during sample preparation alters microRNA content of plasma. PLoS One, 2011, 6: e24145

31 Chen X, Liang H, Guan D, Wang C, Hu X, Cui L, Chen S, Zhang C, Zhang J, Zen K, Zhang CY. A combination of Let-7d, Let-7g and Let-7i serves as a stable reference for normalization of serum microRNAs. PLoS One, 2013, 8: e79652

32 Han HS, Jo YN, Lee JY, Choi SY, Jeong Y, Yun J, Lee OJ. Identification of suitable reference genes for the relative quantification of microRNAs in pleural effusion. Oncol Lett, 2014, 8: 1889-1895

33 Selth LA, Tilley WD, Butler LM. Circulating microRNAs: macro-utility as markers of prostate cancer? Endocr Relat Cancer, 2012, 19: R99-R113

34 Lee LW, Zhang S, Etheridge A, Ma L, Martin D, Galas D, Wang K. Complexity of the microRNA repertoire revealed by next-generation sequencing. RNA, 2010, 16: 2170-2180

35 Kubiczkova L, Kryukov F, Slaby O, Dementyeva E, Jarkovsky J, Nekvindova J, Radova L, Greslikova H, Kuglik P, Vetesnikova E, Pour L, Adam Z, Sevcikova S, Hajek R. Circulating serum microRNAs as novel diagnostic and prognostic biomarkers for multiple myeloma and monoclonal gammopathy of undetermined significance. Haematologica, 2014, 99: 511-518

36 Jones CI, Zabolotskaya MV, King AJ, Stewart HJ, Horne GA, Chevassut TJ, Newbury SF. Identification of circulating microRNAs as diagnostic biomarkers for use in multiple myeloma. Br J Cancer, 2012, 107: 1987-1996

37 Yoshizawa S, Ohyashiki JH, Ohyashiki M, Umezu T, Suzuki K, Inagaki A, Iida S, Ohyashiki K. Downregulated plasma miR-92a levels have clinical impact on multiple myeloma and related disorders. Blood Cancer J, 2012, 2: e53

38 Sevcikova S, Kubiczkova L, Sedlarikova L, Slaby O, Hajek R. Serum miR-29a as a marker of multiple myeloma. Leuk Lymphoma, 2013, 54: 189-191

39 Yu J, Qiu X, Shen X, Shi W, Wu X, Gu G, Zhu B, Ju S. miR-202 expression concentration and its clinical significance in the serum of multiple myeloma patients. Ann Clin Biochem, 2014, 51: 543-549

40 Qu X, Zhao M, Wu S, Yu W, Xu J, Li J, Chen L. Circulating 
microRNA 483-5p as a novel biomarker for diagnosis survival prediction in multiple myeloma. Med Oncol, 2014, 31: 219

41 Hao M, Zang M, Wendlandt E, Xu Y, An G, Gong D, Li F, Qi F, Zhang Y, Yang Y, Zhan F, Qiu L. Low serum miR-19a expression as a novel poor prognostic indicator in multiple myeloma. Int J Cancer, 2015, 136: 1835-1844

42 Huang JJ, Yu J, Li JY, Liu YT, Zhong RQ. Circulating microRNA expression is associated with genetic subtype and survival of multiple myeloma. Med Oncol, 2012, 29: 2402-2408

43 Navarro A, Diaz T, Tovar N, Pedrosa F, Tejero R, Cibeira MT, Magnano L, Rosinol L, Monzo M, Blade J, Fernandez de Larrea C. A serum microRNA signature associated with complete remission and progression after autologous stem-cell transplantation in patients with multiple myeloma. Oncotarget, 2015, 6: 1874-1883

44 Wang J, Huang SK, Zhao M, Yang M, Zhong JL, Gu YY, Peng H, Che YQ, Huang CZ. Identification of a circulating microRNA signature for colorectal cancer detection. PLoS One, 2014, 9: e87451

45 Ohyashiki K, Umezu T, Yoshizawa S, Ito Y, Ohyashiki M, Kawashima H, Tanaka M, Kuroda M, Ohyashiki JH. Clinical impact of down-regulated plasma miR-92a levels in non-Hodgkin's lymphoma. PLoS One, 2011, 6: e16408

46 Zhu C, Ren C, Han J, Ding Y, Du J, Dai N, Dai J, Ma H, Hu Z, Shen $\mathrm{H}, \mathrm{Xu} \mathrm{Y}$, Jin G. A five-microRNA panel in plasma was identified as potential biomarker for early detection of gastric cancer. Br J Cancer, 2014, 110: 2291-2299

47 Simon-Kayser B, Scoul C, Renaudin K, Jezequel P, Bouchot O, Rigaud J, Bezieau S. Molecular cloning and characterization of FBXO47, a novel gene containing an F-box domain, located in the $17 \mathrm{q} 12$ band deleted in papillary renal cell carcinoma. Genes Chromosomes Cancer, 2005, 43: 83-94

48 Saleh EM, Wahab AH, Elhouseini ME, Eisa SS. Loss of heterozygosity at BRCA1, TP53, nm-23 and other loci on chromosome 17q in human breast carcinoma. J Egypt Natl Canc Inst, 2004, 16: 62-68

49 Liu GH, Zhou ZG, Chen R, Wang MJ, Zhou B, Li Y, Sun XF. Serum miR-21 and miR-92a as biomarkers in the diagnosis and prognosis of colorectal cancer. Tumour Biol, 2013, 34: 2175-2181

50 Moreau P, Cavo M, Sonneveld P, Rosinol L, Attal M, Pezzi A, Goldschmidt H, Lahuerta JJ, Marit G, Palumbo A, van der Holt B, Blade J, Petrucci MT, Neben K, san Miguel J, Patriarca F, Lokhorst H, Zamagni E, Hulin C, Gutierrez N, Facon T, Caillot D, Benboubker L, Harousseau JL, Leleu X, Avet-Loiseau H, Mary JY. Combination of international scoring system 3, high lactate dehydrogenase, and $\mathrm{t}(4 ; 14)$ and/or del $(17 \mathrm{p})$ identifies patients with multiple myeloma (MM) treated with front-line autologous stem-cell transplantation at high risk of early MM progression-related death. J Clin Oncol, 2014, 32: $2173-2180$

51 Klein U, Jauch A, Hielscher T, Hillengass J, Raab MS, Seckinger A, Hose D, Ho AD, Goldschmidt H, Neben K. Chromosomal aberrations $+1 \mathrm{q} 21$ and $\operatorname{del}(17 \mathrm{p} 13)$ predict survival in patients with recurrent multiple myeloma treated with lenalidomide and dexamethasone. Cancer, 2011, 117: 2136-2144

52 Marzin Y, Jamet D, Douet-Guilbert N, Morel F, Le Bris MJ, Morice
P, Abgrall JF, Berthou C, De Braekeleer M. Chromosome 1 abnormalities in multiple myeloma. Anticancer Res, 2006, 26: 953-959

53 Takimoto M, Ogawa K, Kato Y, Saito T, Suzuki T, Irei M, Shibuya Y, Suzuki Y, Kato M, Inoue Y, Takahashi M, Sugimori H, Miura I. Close relation between 14q32/IGH translocations and chromosome 13 abnormalities in multiple myeloma: a high incidence of 11q13/CCND1 and 16q23/MAF. Int J Hematol, 2008, 87: 260-265

54 Pichiorri F, Suh SS, Rocci A, De Luca L, Taccioli C, Santhanam R, Zhou W, Benson DM, Jr., Hofmainster C, Alder H, Garofalo M, Di Leva G, Volinia S, Lin HJ, Perrotti D, Kuehl M, Aqeilan RI, Palumbo A, Croce CM. Downregulation of p53-inducible microRNAs 192, 194, and 215 impairs the p53/MDM2 autoregulatory loop in multiple myeloma development. Cancer Cell, 2010, 18: 367-381

55 Karlin L, Soulier J, Chandesris O, Choquet S, Belhadj K, Macro M, Bouscary D, Porcher R, Ghez D, Malphettes M, Asli B, Brouet JC, Bories JC, Hermine O, Fermand JP, Arnulf B. Clinical and biological features of $\mathrm{t}(4 ; 14)$ multiple myeloma: a prospective study. Leuk Lymphoma, 2011, 52: 238-246

56 Paul E, Sutlu T, Deneberg S, Alici E, Bjorkstrand B, Jansson M, Lerner R, Wallblom A, Gahrton G, Nahi H. Impact of chromosome 13 deletion and plasma cell load on long-term survival of patients with multiple myeloma undergoing autologous transplantation. Oncol Rep, 2009, 22: 137-142

57 Di Martino MT, Gulla A, Cantafio ME, Lionetti M, Leone E, Amodio N, Guzzi PH, Foresta U, Conforti F, Cannataro M, Neri A, Giordano A, Tagliaferri P, Tassone P. In vitro and in vivo anti-tumor activity of miR-221/222 inhibitors in multiple myeloma. Oncotarget, 2013, 4: 242-255

58 Di Martino MT, Gulla A, Gallo Cantafio ME, Altomare E, Amodio N, Leone E, Morelli E, Lio SG, Caracciolo D, Rossi M, Frandsen NM, Tagliaferri P, Tassone P. In vitro and in vivo activity of a novel locked nucleic acid (LNA)-inhibitor-miR-221 against multiple myeloma cells. PLoS One, 2014, 9: e89659

59 Nemec P, Zemanova Z, Greslikova H, Michalova K, Filkova H, Tajtlova J, Kralova D, Kupska R, Smetana J, Krejci M, Pour L, Zahradova L, Sandecka V, Adam Z, Buchler T, Spicka I, Gregora E, Kuglik P, Hajek R. Gain of 1q21 is an unfavorable genetic prognostic factor for multiple myeloma patients treated with high-dose chemotherapy. Biol Blood Marrow Transplant, 2010, 16: 548-554

60 Keats JJ, Reiman T, Maxwell CA, Taylor BJ, Larratt LM, Mant MJ, Belch AR, Pilarski LM. In multiple myeloma, $t(4 ; 14)(\mathrm{p} 16 ; \mathrm{q} 32)$ is an adverse prognostic factor irrespective of FGFR3 expression. Blood, 2003, 101: 1520-1529

61 Munker R, Liu CG, Taccioli C, Alder H, Heerema N. MicroRNA profiles of drug-resistant myeloma cell lines. Acta Haematol, 2010, 123: 201-204

62 Palagani A, Op de Beeck K, Naulaerts S, Diddens J, Sekhar Chirumamilla C, Van Camp G, Laukens K, Heyninck K, Gerlo S, Mestdagh P, Vandesompele J, Berghe WV. Ectopic microRNA150-5p transcription sensitizes glucocorticoid therapy response in MM1S multiple myeloma cells but fails to overcome hormone therapy resistance in MM1R cells. PLoS One, 2014, 9: e113842

Open Access This article is distributed under the terms of the Creative Commons Attribution License which permits any use, distribution, and reproduction in any medium, provided the original author(s) and source are credited. 